Article

\title{
Development Path of Industrial Heritage Tourism: A Case Study of Kitakyushu (Japan)
}

\author{
Zhengyuan Zhao ${ }^{1}$ (D) and Zhigao Liu ${ }^{2,3, *}$ \\ 1 School of Humanities, Southeast University, Nanjing 211189, China; 101012036@seu.edu.cn \\ 2 Institute of Geographic Sciences and Natural Resources Research, Chinese Academy of Sciences, \\ Beijing 100101, China \\ 3 College of Resources and Environment, University of Chinese Academy of Sciences, Beijing 100049, China \\ * Correspondence: liuzhigao@igsnrr.ac.cn
}

check for updates

Citation: Zhao, Z.; Liu, Z Development Path of Industrial Heritage Tourism: A Case Study of Kitakyushu (Japan). Sustainability 2021, 13, 12099. https://doi.org/ $10.3390 /$ su132112099

Academic Editor: Colin Michael Hall

Received: 14 September 2021

Accepted: 30 October 2021

Published: 2 November 2021

Publisher's Note: MDPI stays neutral with regard to jurisdictional claims in published maps and institutional affiliations.

Copyright: (c) 2021 by the authors. Licensee MDPI, Basel, Switzerland. This article is an open access article distributed under the terms and conditions of the Creative Commons Attribution (CC BY) license (https:// creativecommons.org/licenses/by/ $4.0 /)$.

\begin{abstract}
Industrial heritage tourism is aimed at promoting sustainable development in the regional social economy. Japan published Heritage Constellations of Industrial Modernization in 2007 and 2008, and treated them as an important resource to promote the activation of the local economy. Evolutionary economic geography offers a useful framework for studying the evolution of industries and has already been applied to study the different types of tourism destinations, what is often unclear, however, is under what conditions declining industrial cities can be transformed into an industrial heritage tourism destination and by whom. Thus, this article tries to employ the EEG approach to understand the development of industrial heritage tourism in Japan, using Kitakyushu City as a case. The case of Kitakyushu City illustrates the importance of initial conditions and stakeholder collaboration in promote the development of industrial heritage tourism. The results of this study also showed that participation of community residents and the application of new technologies, strong support from national and local governments are critical to the new path creation.
\end{abstract}

Keywords: industrial heritage tourism; regional policies; path development; evolutionary economic geography; Kitakyushu City; Japan

\section{Introduction}

Industrial heritage is often considered as the "landscapes of nostalgia" [1]. The potential value of former industrial heritage for promoting the development of the tourism industry has attracted increasing attention worldwide [2,3]. It has been widely accepted that the transformation of industrial landscapes into tourists-based industrial sites would produce not only the direct effects from high tourist arrivals (e.g., creation of employment opportunities and material wealth within the industry), but also the indirect multiplier effects for the local community, for instance, reshaping local images, intensifying new localized consumption desires, promoting local gentrification and creating new investment opportunities while maintaining a low environmental risk [4-12].

Japan, Asia's earliest industrialized country, has been transforming into a postindustrialized society. A large number of former industrial heritages in Japan have been well protected. Three industrial heritages have been listed in World Heritage by UNESCO (United Nations Educational, Scientific and Cultural Organization). Moreover, Japan has the largest number of centennial enterprises in the world, reaching 25,321, much more than that of North America and Europe. Compared with other industrialized countries, Japan's industrial heritages are generally owned by long-lived enterprises, some of these spaces are still in service. Therefore, centennial enterprises often become the most direct stakeholders in the protection of industrial heritages, and play a key role in the transformation into new industrial space for cultural and touristic activities [13]. In other words, under the influence of centennial enterprises, the development of industrial heritage tourism in Japan generally has strong path dependence. 
The City of Kitakyushu in Fukuoka Prefecture was once one of the important heavily industrialized cities and is at the forefront of protecting industrial heritage and promoting the development of industrial heritage tourism in Japan. Some historic industrial sites have been registered on the UNESCO World Heritage Sites of Japan's Meiji Industrial Revolution. Therefore, this study presents Kitakyushu City as an example to understand the industrial heritage tourism development path in Japan, using the key concepts of Evolutionary Economic Geography (EEG).

This article contributes to a small but growing body of scholarship that seeks to understand the development path of industrial heritage tourism. We situate this article at the interface of Evolutionary Economic Geography (EEG) and critical industrial heritage tourism studies. The EEG emphasizes the importance of historical processes and spatial heterogeneity based on evolutionary and complex thinking. The EEG offers a useful framework for studying the growth and decline of traditional manufacturing industries [14], and exploring the emergence and development of service industries, culture and creative industries, and tourism economy $[15,16]$. Although EEG has already been applied to study the different types of tourism destinations [17-19], what is often unclear is under what conditions declining industrial cities can be transformed into an industrial heritage tourism destination and by whom.

Thus, this article tries to employ the EEG approach to understand the development of industrial heritage tourism in Japan. Based on the critical concepts of EEG such as "path dependence" and "path creation", this article will assess how tourism promotes the transformation of industrial heritages and produces regional effects. Specifically, this article will focus on the conditions under which the development path of industrial heritage tourism as a new type of economic activities emerged, the roles of the declining traditional industries, and stakeholders in the transformation process.

The article is organized as follows. In the second section, we will specify the theoretical background of path dependence theory and the path dependence approach to destination evolution and old industry area transformation. In the third section, the method we used will be introduced. In fourth section, the historical backgrounds of the Kitakyushu City as an industrial city and the current national strategies for developing industrial heritage in Japan will be provided. In the fifth section, we will trace the historical process of developing industrial heritage tourism in Kitakyushu. Finally, we will discuss the research findings and present some conclusions.

\section{Literature Review}

\subsection{EEG and Restructuring of Old Industrial Areas}

Industrial heritage tourism refers to "the development of touristic activities and industries on man-made sites, buildings and landscapes that originated with industrial process of earlier periods" [20]. One way of understanding the changing trajectories of regional growth and decline is to draw upon strands of evolutionary thinking, especially evolutionary approaches in economics that eschew biological analogy and emphasize that path dependence is socially constituted [21]. In this process, EEG is becoming the primary paradigm for studying industrial restructuring of old industrial areas because of its attention to the evolutionary process, mechanism, and effect of spatial organization of economic production, distribution, and consumption, and geographical laws behind it [14]. The EEG advanced our understanding of the dynamics and development path of regional and industrial growth and decline through its key concepts of path dependence, lock-in, diversity, resilience, and path development.

Path dependence implies that the development of a system tends to follow or be subject to its past behavior, which endows its development path and results in historical inertia [22]. Lock-in, which combines the viewpoints of historical contingency and the autofrettage effect, refers to the phenomenon in which technology, industry, or economy develops along a specific path [23]. In the context of a long-time sequence, lock-in has an open result, not necessarily constituting a barrier to reconstruction [24]. 
The existing empirical studies focused mainly on the reconstruction dilemma of old industrial areas. However, less attention was paid to the protection and utilization of old industrial areas, especially industrial heritage. Promoting the development of a new industrial path is an important way to reconstruct an old industrial area [25]. The EEG scholars insist that a new industry tend to be derived from technically related industries [14,22]. The evolution of the regional industry is related to historical events and deliberate strategies, and it is also restrained by a place-specific political and economic system [26].

Meanwhile, based on the concepts of continuity, selection, and novelty in generalized Darwinism, and in combination with the externality theory in urban economics, Frenken et al. coined the term of related variety and they held that new industries often emerge from a technology-related old industry [27]. Moreover, empirical studies have verified that creating a new industry uniformly follows the relatedness rule, whether in the case of endogenous differentiation or exogenous implantation [28]. That is, the higher the interindustry technology relevance in a place, the more likely that the knowledge interaction and spillover will occur, and the more likely the new industry will be born [29].

In recent years, some EEG scholars called for the incorporation of the perspective of institution and agency into the evolutionary framework, and argued that the established path may be transformed by external schocks [21] and government policies play a key in recreating a new path [30]. Local political and economic elites and their networking and relation are important forces driving the formation of new industries [21,31]. Due to the (conceived) crisis (for instance, the decline of the traditional industries), they take strategic actions to reshape the development path. New path creation often involves multiple dimesions: technological, institutional, organizational, and multiscalar factors [32,33].

Consequently, some economic geographers have begun to reflect on the dependence theory of traditional paths, insisting that the path is a process full of plasticity, and have proposed the concept of regional industrial path development to summarize the path evolution mechanisms of different types [22,23]. They believe that there are many mechanisms for the reconstruction of old industrial areas in different institutional environments: path persistence/extension, path exhaustion, path importation, path renewal, path branching, path diversification, and new path creation [34-37]. Compared with traditional path creation, the concept of path development treats historical function more dialectically, paying attention to regional prerequisites and emphasizing the active role of multi-subject initiative, so that it can more precisely explain the reconstruction process, mode, and mechanism of old industrial areas.

\subsection{Industrial Heritage Tourism for Sustainable Urban Development}

With the decline and transformation of traditional manufacturing industries in the mid-20th century, Western Europe entered the post-industrial era and began to take actions to protect industrial heritage $[38,39]$. Previous studies on industrial heritage in Western Europe and North America are characterized by extensive topics, diverse research methods, rich research perspectives, and content [40]. The early discussion on industrial heritage tourism was carried out on the basis of industrial archaeology and heritage protection. It is considered that industrial heritage can retain urban memory, and summarize and reflect on the pattern of industrial development [41]. As UNESCO and other institutions began to pay attention to the activation and utilization of industrial heritage, the development of cultural tourism based on industrial heritage has become a key means of urban industrial adjustment and urban brand reconstruction. Many cities in Western Europe and North America have also successively increased recreational and leisure facilities in old industrial areas, ports, and other places, and built central business districts with recreational, leisure, business, and other functions to promote urban regeneration [2]. Entering the 21st century, the increasing number of cities have emphasized the recreational utilization of industrial heritage resources in a broader sense [42-45]. Through the environmental improvement of 
industrial heritages, the development of cultural and leisure industry will help to promote regional industrial transformation and sustainable development.

Industrial heritage tourism constitutes a unique value for the post-industrial society [46]. For the declining old industrial areas, tourism creates new job opportunities and improves regional images, consequently convincing local residents, especially younger people, to stay [47]. Industrial heritage becomes an essential element in economic development, the unique social value of heritage is sufficient reason to protect and maintain it. The positive impact of industrial heritage is also significant for sustainable urban development [48]. Thus, international organizations including UNESCO and UNWTO (The World Tourism Organization) have zealously promoted the development of industrial heritage tourism.

So far, only a few studies have applied these concepts of EEG in sustainable tourism contexts [49]. Brouder illustrates how recent research linking EEG and tourism issues has addressed either path dependence in established tourism destination regions or coevolution within complex regional systems including non-tourism development paths [50]. In recent years, more attempts have been made to study the impact factors of path creation, such as macro environment, national policies, events and activities, destination knowledge networks, and stakeholder collaboration [51]. For the EEG approach, tourism governance is the process of managing tourist destinations through synergistic and coordinated efforts by governments at distinct levels and different capacities [52,53]. These participatory processes and goal setting must be understood with historical and cultural lenses [54].

\section{Methodology}

This empirical study on Kitakyushu City draws on textual analysis, case study, and semi-structured interview. According to the EEG thanking, industrial evolution and transformation often involve the multiple factors from various geographical scales. However, it is driven mainly by profit-oriented enterprises and their networking and relations with other stakeholders that are constrained by the macro- and meso-level environments (e.g., global and national economics, technological and institutional systems, local government policy, customer behavior preferences).

Thus, besides enterprise strategy and action, the key information on the changes in government policy and responses of other stakeholders is required to study the transformation of Kitakyushu City into one modern tourist destination of Japan. In this study, textual analysis is used to examine the evolution of policy discourses related to the industrial heritages in Kitakyushu City, and the case study focusses on the strategies of important enterprises who take a role in promoting the development of industrial heritage tourism while semi-structured interviews are employed to understand the motives and reasons behind new actions and measures that are taken by key stakeholders (enterprises, governments, and others).

The materials for textual analysis were collected from newspapers and journals and the local government websites. They are 56 policy documents and plans publicly issued by the different levels of governments, from the central government of Japan through the Fukuoka Prefecture to Kitakyushu City and the town hall of wards in Kitakyushu City. Our textual analysis focuses not only on industrial heritages-related content (policy, funding, or regulation announcements, etc.), but also examines how the government positioned and reimagined Kitakyushu City.

The case studies method can provide detailed information on specific actors. In Japan, enterprises are often the principal actors in protecting and developing industrial heritage [13]. We conducted a case study on the significant enterprises in Kitakyushu City to examine why and how they promoted the development of local industrial heritage tourism. We traced the history of significant enterprises, but focused on the key historical events and measures adopted by significant enterprises to transform obsolete industrial buildings into creative and cultural spaces. Hence, the case study data can provide important evidence and insights into the evolutionary process of tourism development. 
The semi-structured interview was also used in this study. The interviews with the key stakeholders including the government, NGO, local enterprises, and residents, were conducted three times from February 2017 to September 2019. Each interview lasted 15-40 min, and most were recorded, transcribed, and cross-checked with the interviewees. The major objectives of these interviews were first to understand the reasons for and methods of transforming these industrial buildings to new industrial spaces especially for touristic activities, and second to investigate the roles and responsibilities in promoting industrial heritage tourism development in Kitakyushu City. In addition, the semi-structured interview allowed us to stimulate dialogues with the interviewees [55], around the regional policies and social-economic backgrounds, development of new tourism products, and specific actions and measures by governments and enterprises.

\section{Regional and National Backgrounds}

\subsection{Rise and Fall of KITAKYUSHU as an Industrial City}

Kitakyushu City is a municipal-level administrative area, at the second level of Japan's contemporary administrative hierarchy, below the prefecture, but above the wards level. Since it is located at the northernmost part of the Kyushu prefecture on the island of Kyushu, just south of the Japanese main island, its name literally means "North Kyushu City" in Japanese. Owing to the geographical location, it is often regarded as a Japanese gateway to Asian economies [56]. The Kitakyushu City was formed in 1963 through the merger of five older and smaller cities centered on the historic city of Kokura. At present, Kitakyushu comprises seven wards (Moji, Kokurakita, Kokuraminami, Wakamatsu, Yahatahigashi, Yahatanishi, and Tobata) (see Figure 1), with an area of around $488 \mathrm{~km}^{2}$ and a population of around 940 thousand in 2020, making it the second-largest city in the Fukuoka Prefecture.

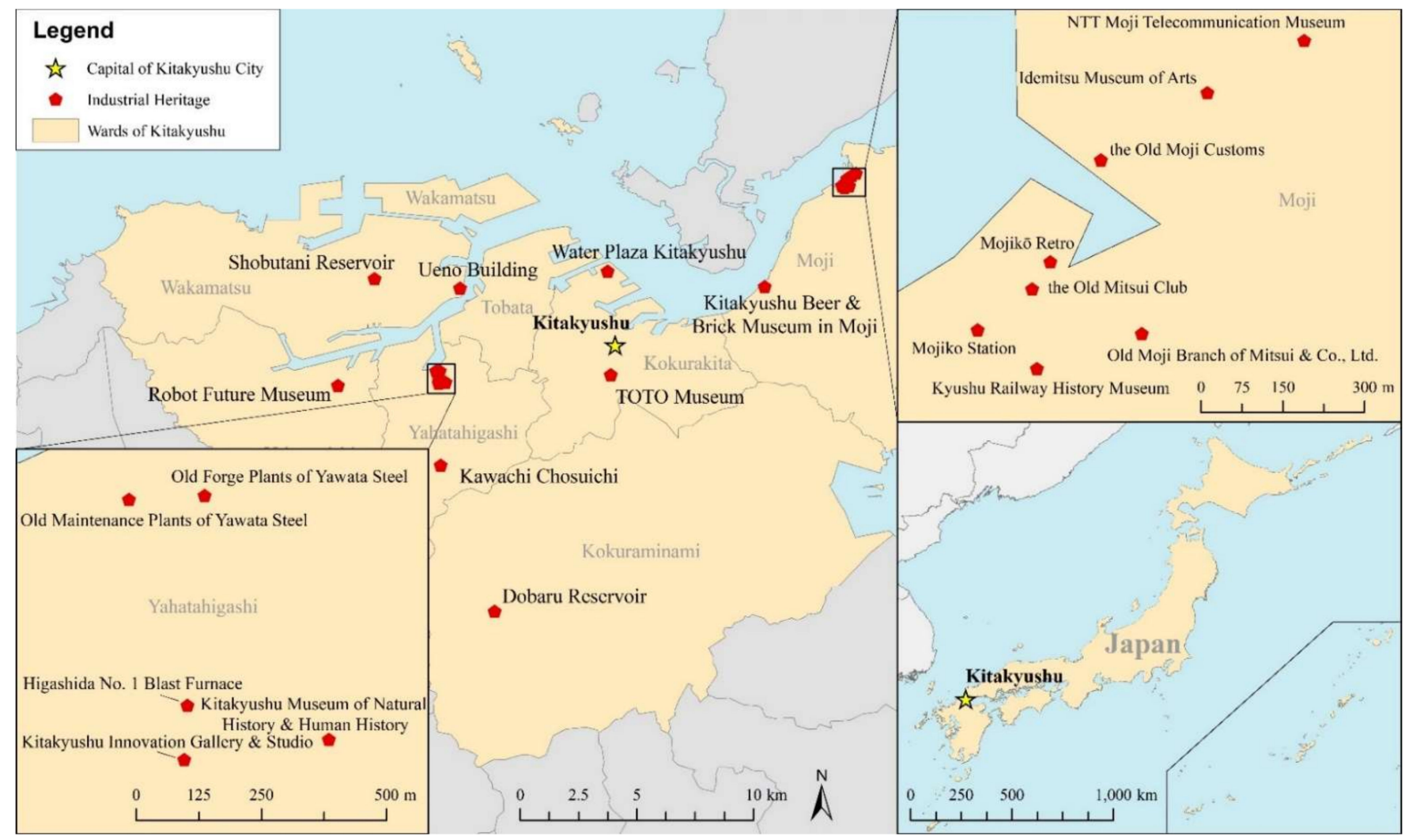

Figure 1. Main Industrial Heritage in Kitakyushu City, cartography: Jiashun Xue.

Historically, Kitakyushu was a small fishing village, however, it played a lead role in Japan's Meiji Industrial Revolution. The industrial development in Kitakyushu dates back to the establishment of the Yawata Steelworks in 1901. Thanks to the easy access of raw 
materials, the Meiji government in Japan established the first nation-wide integrated iron and steel plant at Yawata, by using coal from the Chikuho coalfield (the largest coalfield in Japan at the time) and iron ore shipped from China. By 1913, the Yawata Steelworks was producing 85 percent of Japan's steel [57]. Later, the Kitakyushu City developed rapidly into an important industrial city of steel, machinery, ceramics, and chemistry in Japan [58]. The high-speed industrial development led to rapid population growth in Yawata and nearby cities during the early 20th century, which became a unified functional region [59].

The Second World War left Kitakyushu City in ruins. However, during the Korean War (1950-1953), the United States' demand for weapons and ammunitions stimulated the resurgence of this region as a significant post-war manufacturing area. The Yawata Steelworks was a prime driver of regional economic recovery. However, after the 1970s, the economic development model of Kitakyushu as a "company" town centralized around one single industrial sector was challenged. On one hand, the rapid development during the 1950s and 1960s had led to air and water pollution which worsened Kitakyushu's economy based on heavy and chemical industries. The sea area near the city was once dubbed the "sea of death" owing to the deterioration of water quality. The deterioration of the living environment has led to the outflow of population, particularly the Young. On the other hand, the postindustrial transformation of both the global and Japanese economies reorganized the economic geography of Japan, in favor of the Tokyo metro area. Nippon Steel, at that time the owner of the Yawata Steelworks, shifted its focus toward the new Kimitsu Factory near Tokyo and relocated its development and research center. With the relocation of many industrial facilities, a large quantity of industrial buildings was left unused in the 1970s in Kitakyushu City, including coal mines, ceramics, steel, railways, ports, and waterworks [60]. This study will examine the process of transforming obsolete industrial buildings into new industrial spaces, especially for touristic activities.

\subsection{National Strategy for Developing Industrial Heritage in Japan}

The Japanese government has regarded industrial heritage as a vital tourism resource for more than ten years and has advanced the process of regional revitalization in Japan. Since the 1990s, with the decline of birth rate and the population aging, the industries and population have been further concentrated around Tokyo, and many parts of Japan have been facing the problem of the decline in population and enterprise numbers. According to the "Act on Overcoming Population Decline and Vitalizing Local Economy in Japan" which was enforced in 2014, all prefectures and municipalities were required to formulate a Regional Revitalization Strategy to improve the vitality of local communities, by rediscovering and making full use of their specialties and strengths [61]. Restoring and exploiting former industrial sites for touristic purposes is viewed by many Japanese cities as a useful instrument of regional restructuring and economic development.

Against this background, the central government of Japan began to highlight the importance of industrial heritage as an essential industrial resource and a new economic engine, rather than simply as a category of cultural relics. In 2007 and 2008, the Ministry of Economy, Trade, and Industry (METI) classified the heritage of similar topics in the form of stories on the basis of local declaration and successively identified "33 Heritage Constellations of Industrial Modernization" and "33 Heritage Constellations of Industrial Modernization Vol. 2", respectively, totaling 1115 items [62,63]. Apart from the four traditional industrial regions located along the Taiheiyo Belt, which claim many items, the items are spatially distributed throughout Japan.

The Heritage Constellations of Industrial Modernization of METI is different from the general survey of cultural relics, based more on the industrial significance in the process of modernization of Japan, focusing on the economic value and development function of heritage, and facilitating the cooperation and promotion between local governments and industries [64]. Under the guidance of national policy, industrial heritage was increasingly regarded by traditional industrial cities as an important resource to rejuvenate the local economy [65]. In other words, industrial heritage was commercialized for touristic 
activities, since it was expected not only to meet the new needs of tourists (e.g., night sightseeing, leisure, and cultural creativity, but also to transform industrial structure and increase employment.

\section{Case Study of Kitakyushu City}

\subsection{Industrial Heritage Tourism Development in Early Years}

As we mentioned above, because of both the global and national postindustrial transformation and local pollution, since the 1970s, many industrial facilities in Kitakyushu City were forced to be relocated, and some former industrial spaces were transformed for recreational and touristic activities. The most famous was the Yawata Steelworks of Nippon Steel Corporation, which was often regarded as an important symbol of Japan's modernization. One of its landmark buildings, Higashida No. 1 Blast Furnace, stopped operation in 1972 due to the steel industry restructuring (Figure 2). The following year, after environmental improvement (planting cherry and other trees around it), this place was transformed from a traditional industrial landscape into a space for leisure and relaxation (a memorial square open to the public).

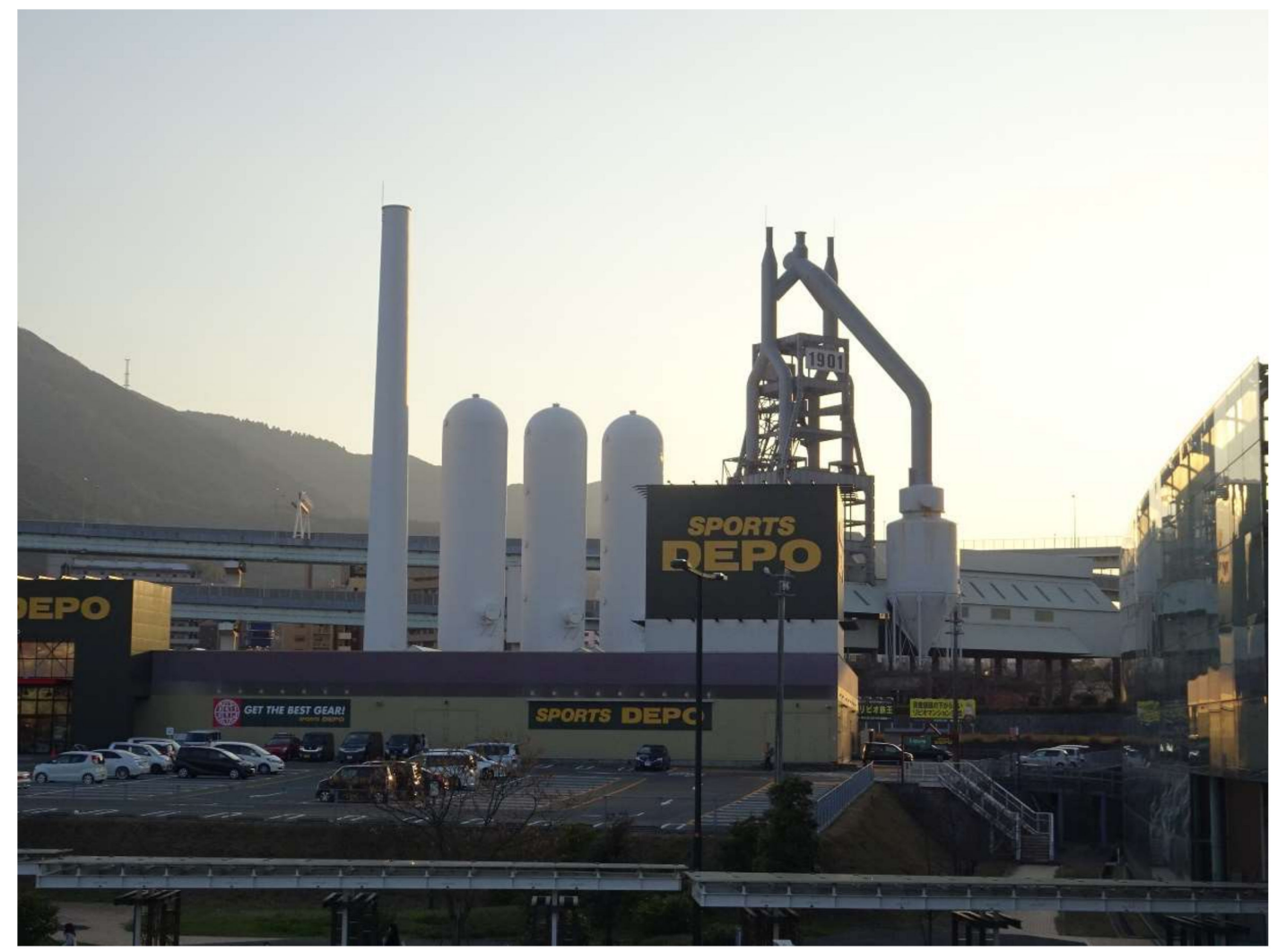

Figure 2. Higashida No. 1 Blast Furnace, photography: Toshiyuki Morishima.

In 1989, the Nippon Steel Corporation planned to use its idle space after the relocation of the factory for commerce and tourism development, where commercial residences, theme parks, luxury hotels, etc. were set up. Its landmark building, Higashida No. 1 Blast Furnace was supposed to be demolished. However, this led to a protection movement spontaneously organized and volunteered by local residents, many of whom were former employees of the Yawata Steel Works. With active lobbying from all walks of life, the government of the Yawata District and the municipal government of Kitakyushu finally identified the Blast Furnace as a National Historic Site in 1996, thus preserving it. The project has thus become a model for local residents in Japan to promote the protection of industrial heritage from the bottom to the top. After the renovation, the Blast Furnace was opened to ordinary tourists before the Kitakyushu Expo Festival in 2001. Concomitantly, 
the refining furnace and special train for transporting coal and iron ore near it were also preserved and exhibited. With the increase in the number of tourists, the Nippon Steel Corporation opened up a unique viewing site, equipped it with detailed signs and guides, and arranged its employees to make oral explanations when there were a large number of tourists. A few of them commented:

For us, it is not so much to develop tourism as to preserve better and display the history of our enterprise, so we do not care about tourism revenue.

Many local citizens are so active that they volunteer to help make oral explanations on weekends. We applaud this very much.

All these early tourism facilities of industrial heritage were directly undertaken and managed by the Nippon Steel Corporation. As the development of industrial heritage tourism is an integral part of corporate social responsibility and enhances the corporate image and reputation, the Nippon Steel Corporation chose to open the site to the public free of charge. In fact, although Higashida No. 1 Blast Furnace is used for preservation and exhibition, most buildings of the Yawata Steel Works are still in use and operation today, including the earliest First Head Office building, which was completed in 1899, and the earliest steel structure building in the Japan Maintenance Plants, which has been in operation for more than 110 years. Old Forge Plants, which is now used as the corporate archive center, has not yet been opened to the general public. Therefore, a series of enterprise-led planning and construction of industrial heritage exhibition spaces can only be regarded as the extension of the established path.

Likewise, Mojiko, another important industrial heritage site of Kitakyushu, was founded in 1889 and initially developed as a vital coal transportation port, which gradually became an important commercial port and an important center of railways, logistics, finance, and trade in modern Japan. However, in the second half of the 20th century, with the decline of heavy industry and the launch of the Kanmon Tunnel, the port declined gradually in terms of both freight and passenger transport. Concurrently, the previous finance and trade enterprises, and other commercial businesses out-migrated in succession, and many modern industrial factories and commercial buildings were left vacant. The Mojiko Station in Moji Ward is the only station building as an industrial heritage in Kitakyushu City, which was designated as one of two named as an Important National Cultural Property of Japan (the other is Tokyo Station). The Mojiko Station was built in 1914 in the Renaissance style, modeled on the Termini Station in Italy, and is still in operation. Another essential industrial heritage is Kitakyushu Beer \& Brick Museum in Moji. This museum was transformed from the main building of the Kyushu factory in 2005. This factory was established in 1913 by Sapporo Beer, but was relocated in 2000. Since then, it has been idled before it was redeveloped as a museum.

Other former industrial spaces were successively transformed into cultural and commercial facilities. For example, the Kyushu Railway History Museum located near Mojiko Station was the previous headquarter of the Kyushu Railway Company established in 1891. After renovation, the museum was officially opened to the public in 2003, which was mainly used to display the storied history of Kyushu's railway system. To enhance the tourists' experience function, the historical museum introduced a simulated driving cab and amusement space for children.

Similarly, the NTT Moji Telecommunication Museum was transformed from the Moji Post and Telecommunications Office which was built in 1924. After its relocation, NTT developed the space into a telecommunication-themed museum and opened it to the public free of charge. The museum exhibits a variety of historical materials on the telegraph and on the telephones that were used in the past in Japan. Many historical museums were established by private enterprises. The phenomenon is attributed partly to the industrial heritage-related preferential policies from the central government of Japan, as a senior staff of the NTT Moji Telecommunication Museum pointed out when he was interviewed: 
The Japanese government has implemented tax relief measures for private enterprises to set up museums. The Agency for Cultural Affairs also encouraged support projects for creative activities of museums cooperating with local governments. Thus, enterprises have much enthusiasm to apply for a certain amount of funds.

\subsection{Heritage Transformation Drion by Regional Policies}

While local enterprises spontaneously launched the protection of industrial heritage and the construction of museums, Kitakyushu's municipal government formulated a series of development plans. In 1988, the municipal government officially proposed the Renaissance Plan, which repositioned the development direction of Kitakyushu City in the 21st century as "a green industrial city centered on industries of science and technology, environmental protection and tourism by promoting the transformation of old industrial areas." In 1991, in order to promote the revitalization of local culture, the municipal government established the Cultural Promotion Fund to support various art and cultural activities launched and organized by local residents spontaneously.

For more than 20 years, the Kitakyushu City has made remarkable achievements in environmental improvement and scientific and technological innovation. It was awarded the first "Eco-City", and "Green Asia International Strategic Comprehensive Special Zone" by the central government of Japan, and "one of four Green Growth Model Cities" by OECD (Organization for Economic Cooperation and Development). In April 2007, the Kitakyushu Innovation Gallery \& Studio (KIGS) was opened in the original site of the Yawata Steelworks. It stimulated the emergence of a cluster of cultural sites, for instance, the Kitakyushu Museum of Natural History \& Human History, the Kitakyushu Environment Museum, and the Higashida No. 1 Blast Furnace.

In recent years, inspired by the theory of Creative Cities, the municipal government further formulated the Cultural Promotion Plan in 2010 to build Kitakyushu as a "city with rich education and culture", and special funds were created to support the establishment of local art galleries and museums. Under the government supports, some industrial heritage buildings were transformed into the places for the inheritance of traditional skills to cultivate future artists and folk craftsmen. Furthermore, the municipal government of Kitakyushu created a number of spectacular factory night views as the Kitakyushu Cityscape view at night. The nighttime views include the complete-set cluster of equipment of the past chemical factories, ironmaking plants, and huge chimneys. Thus, Kitakyushu City has become one of the three most beautiful cities at night in Japan.

A group of abandoned traditional industrial buildings was registered in the 2000s as national cultural assets, such as the Ueno Building, the Old Moji Customs, and the Kawachi Chosuichi (Figure 3). The municipal government reached an agreement of property rights transfer with some of their original owners and spent money rebuilding them for public cultural spaces. For example, the Old Moji Branch of Mitsui \& Co., Ltd. the highest office building in Kyushu in the Taisho period (1912-1926), has been owned by the Kyushu Railway Company since World War II. In 2005, its ownership was transferred to Kitakyushu City. Later, the municipal government made a series of reconstructions to make it an important cultural space with a concert hall, an art gallery, a historical data room, and a maritime information center. An additional example is the Idemitsu Museum of Arts. It was the former site of the material warehouse built by the petroleum company Idemitsu Kosan in the early 20th century and was opened to the public in 2000, displaying a large number of calligraphy and painting works and ceramic ware.

However, to reduce the burden of local finance, the municipal government of Kitakyushu has consciously transformed some spaces into commercial spaces such as cafes, restaurants, and wedding venues. For example, the Old Moji Customs in the Moji ward, was opened to the public in 1995. In addition to the exhibition space for introducing customs history, commercial facilities, such as a retro cafe, art gallery, and prospect room, were given for lease. The Old Mitsui Club was built by Mitsui Co., Ltd. in 1921 as a reception center to provide accommodation for VIPs. Albert Einstein stayed here during his visit 
to Japan with his wife in 1922. On the second floor of the Old Mitsui Club, the "Einstein Memory Showcase" is displayed together with the life and creation of Fumiko Hayashi, a Japanese writer born in Moji, while the first floor of the Old Mitsui Club has been transformed into a restaurant.

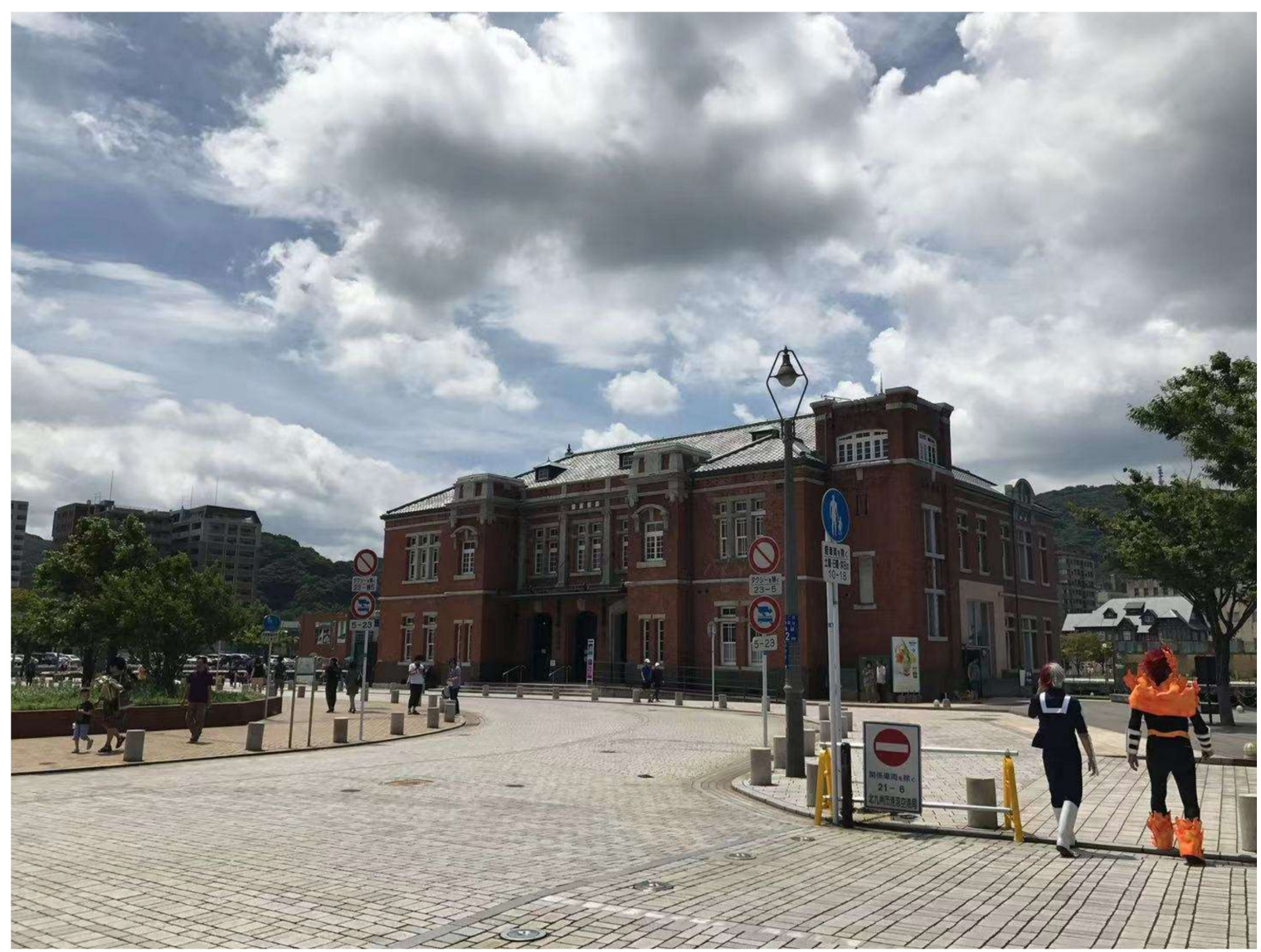

Figure 3. Mojiko Retro in Kitakyushu, photography: Zhengyuan Zhao.

With the recognition of the Heritage Constellations of Industrial Modernization since 2007, the industrial heritage has been regarded by local governments in Kitakyushu City as an important tourism resource. With their efforts, many industrial heritage sites have been included in different categories. First, the Yawata Steelworks and the Old Moji Customs were selected into " 33 Heritage Constellations of Industrial Modernization" as heritage constellations of the modern steel industry and heritage constellations of the coal industry in Kyushu and Yamaguchi, respectively. Later, more industrial heritage sites, modern buildings, public facilities, and museums distributed in various parts of the city were selected into "33 Heritage Constellations of Industrial Modernization Vol. 2" in 2009 (see Table 1).

Table 1. Heritage Constellations of Industrial Modernization in Kitakyushu City.

\begin{tabular}{ll}
\hline Major Heritage in Kitakyushu & Heritage Constellations \\
\hline Higashida No. 1 Blast Furnace; Yawata Steel Works et al. & Heritage constellations of modern steel industry \\
Old Moji Customs; Old Mitsui Club et al. & Heritage constellations of coal industry in Kyushu and Yamaguchi \\
JR Mojiko Station & Heritage constellations of train ferry \\
Dobaru Reservoir: Shobutani Reservoir & Heritage constellations of modern water supply \\
NTT Moji Telecommunication Museum & Heritage constellations of modern telecommunications \\
Buildings in Kyushu Institute of Technology & Heritage constellations of engineering education \\
Kitakyushu Beer \& Brick Museum in Moji; TOTO Museum et al. & Heritage constellations of ceramic industry in North Kyushu \\
\hline
\end{tabular}


The municipal government of Kitakyushu began to actively cooperate with the central government and surrounding areas in the later 2000s to boost the declaration of world heritage. After the Kyushu and Yamaguchi Modern Industrial Heritage Group was included in the Tentative List of World Heritage in January 2009, as Japan's first serial nomination project, it received generous support from the central and local governments. The central government took the lead role in promoting cross-regional cooperation to initiate and direct the World Heritage nomination process. Finally, in 2015, the First Head Office Building, the Maintenance Plants, the Old Forge Plants, and other modern buildings of Yawata Steelworks were included in The World Cultural Heritage List as part of the Sites of Japan's Meiji Industrial Revolution.

\subsection{The Formation of Industrial Tourism and Its Expansion}

Although the industrial heritage tourism in Kitakyushu emerged at the end of the 20th century, driven by local manufacturing enterprises, it entered a stage of rapid development after 2010. In 2010, the Chamber of Commerce and Industry in Kitakyushu City officially declared industrial heritage as a strategic tourism resource to revitalize the region. In 2014, the municipal government of Kitakyushu, Kitakyushu Chamber of Commerce and Industry, and Kitakyushu Tourism Association jointly established the Kitakyushu Industrial Tourism Center (KITC) and launched a one-stop industrial tourism window service. The KITC works with travel agencies to develop tourist routes, and hires approximately 80 local citizens as tour guides.

With the expansion of the industrial heritage tourism, in recent years tourists have not only visited factory buildings and facilities, but also showed a strong interest in visiting the living areas of workers in the past industrial era. Thus, the KITC has completed the planning of teaching materials and projects in cooperation with local primary and secondary schools. Some individuals remarked:

I worked here before retirement. I would like to introduce my own past life experiences to arouse the common feeling of our generation. Many students from local and surrounding primary and secondary schools come here for school trips, and teachers lead them to conduct various surveys and interviews.

The vigorous development of industrial heritage tourism has also directly driven the development of science and technology tourism, environmental tourism, and other types of industrial tourism. A head of KITC commented:

Traditionally, the impression of Kitakyushu by ordinary Japanese was mainly focused on Kanmon Straits and Mojikō. However, in recent years, we have developed new projects in cooperation with well-known enterprises centered on industrial heritage and high technology, and actively explored the MICE market, which has tremendously changed the destination image of the entire city.

As the KITC summarized, the sources of industrial tourism in Kitakyushu consists of industrial heritage, factory tour, and factory night view. By combining industrial heritage with modern cityscape and high-tech experience sightseeing, Kitakyushu has become a major industrial tourism destination of Japan. First, as a model of successful transformation among Japan's heavy industrial cities, the municipal government of Kitakyushu created several research and study tourism projects for environmental protection, for instance, the visits of the Water Plaza Kitakyushu (an integrated seawater desalination and sewage reuse system applying cutting-edge technologies) and other environmental protection and recycling technology facilities.

Second, the municipal government developed industrial tourism projects with advanced technology in cooperation with local enterprises. Under the generous government support, for instance, Zenrin (a mapping and navigation software enterprise), TOTO (a sanitary ceramics manufacturer), and Yaskawa Electric (a leading global manufacturer of industrial robots) have been active in developing industrial tourism. Yaskawa Electric es- 
tablished the Robot Future Museum, and TOTO set up the Enterprise Information Museum in 2015.

Third, KITC worked with tourism agencies to integrate various former industrial facilities and the night views into tourist routes. To satisfy the increasing demand of night sightseeing tourists, the municipal government and travel companies have cooperated to officially launch a new project of factory zone night view suitable for office workers since 2011, so that tourists can enjoy the night view in various parts of the city by bus and cruise ships. Moreover, in Mojikō Retro, the "Romantic Lantern Festival in the Nostalgic Area of Moji" has been launched in winter since 2013. The historical buildings and trees around the Mojikō Retro are illuminated to create a romantic atmosphere. In addition, KITC has helped develop and promote new tourist souvenirs for local unique products. As a result, the number of industrial sightseeing tourists increased from 428,000 in 2014 to nearly 700,000 in 2019. A senior staff at KITC pointed out in our interview:

We will also invite film and television crews and cartoonists to find views from the old landscape preserved by industrial heritage. These works can not only contribute to the spread of Kitakyushu industrial heritage at home and abroad, but also attract fans and tourists who pursue a pilgrimage to a holy land.

The combination of night view and high-tech sightseeing in industrial tourism indicates that the industrial tourism in Kitakyushu City has adopted a new path, which leads the increasing number of visitors, mainly from Japan, to Kitakyushu City, particularly to its industrial heritage areas (see Table 2). Although local governments are often considered to play a guiding role, both local enterprises and residents are involved in promoting industrial tourism. Thus, the actors involved in the industrial tourism became diverse and constitute a local collaborative network. Generally speaking, because many enterprises tend to be short of in professional talents and funds, in this network the local governments have played a critical role in promoting the transformation of industrial heritage into tourism resources. They often assume the primary responsibility for formulating development planning, investment promotion, and fundraising. In order to strengthen cross-departmental coordination, the Council for the Tourism Promotion was established under the leadership of the municipal government, consisting of various local government departments.

Table 2. The number of visitors of Kitakyushu City and industrial heritage areas. Unit: thousands.

\begin{tabular}{|c|c|c|c|c|c|c|c|}
\hline & 2011 & 2012 & 2015 & 2016 & 2017 & 2018 & 2019 \\
\hline \multicolumn{8}{|c|}{ Kitakyushu City } \\
\hline Number of Visitors & 22,417 & 25,172 & 25,714 & 25,433 & 25,324 & 23,194 & 24,208 \\
\hline Foreigners & 65 & 114 & 252 & 349 & 682 & 691 & 556 \\
\hline \multicolumn{8}{|c|}{ Main Industrial Heritage Areas } \\
\hline City Center of Kokura in Kokurakita & N.A. & N.A. & 5659 & 5821 & 5833 & 6290 & 6513 \\
\hline Yawata Higashida Area in Yahatahigashi & N.A. & N.A. & 2422 & 2211 & 2525 & 727 & 708 \\
\hline Mojiko Area in Moji & N.A. & N.A. & 2321 & 2475 & 2543 & 2184 & 2436 \\
\hline Total & N.A. & N.A. & 10,402 & 10,507 & 10,901 & 9201 & 9657 \\
\hline Percentage of Main Industrial Heritage Areas in Total Kitakyushu & N.A. & N.A. & $40.45 \%$ & $41.31 \%$ & $43.05 \%$ & $39.67 \%$ & $39.89 \%$ \\
\hline
\end{tabular}

Source: elaborated from Industry and Economics Bureau of Kitakyushu City (https://www.city.kitakyushu.lg.jp/san-kei/file_0065.html, accessed on 11 October 2021). Note: N.A. = not available.

\section{Discussion}

\subsection{A Model of Industrial Heritage Tourism Evolution Path}

Our findings suggest that the industrial heritage tourism in Kitakyushu has experienced lock-in, path dependency, path creation and development, and adaption of local tourism phases. The emergence of the industrial heritage tourism is not only influenced by 
"random events" or "small chances" (e.g., heritage protection or cultural policy), but also basically rooted in its initial conditions, especially preexisting industrial cultural resources.

As shown in Figure 4, a model for industrial heritage tourism in Kitakyushu can be summarized using the theory of EEG. The vertical axis consists of three levels: the phenomenon, the action, and the ideological level [66]. These three levels represent the visible and experience-able appearance of tourists and residents, measures and behaviors that promote sustainable socio-economic development, and the ideas and principles that determine the other two levels, respectively. The horizontal axis is the development course of this tourism destination from lock-in, path dependence, path creation, and path development to the adaptation phase of local tourism [67].

Specifically, in the lock-in phase, tourism activities were limited to a small minority of amateurs in industrial heritage. The government and enterprises knew little about industrial heritage tourism; discussion of industrial heritage focused mainly on survey and protection at the action level and also on the institutional legacy at the ideological level. In the path dependence phase, the transformation of industrial heritage was spontaneously driven by local enterprises and NGOs. The new path was created by the changes in macrolevel policies and also the microenvironment. In this phase, the local government promotes the transformation of industrial heritage through urban renewal and cultural policies, and industrial heritage tourism begins to emerge.

\begin{tabular}{|c|c|c|c|c|c|}
\hline Ideology & $\begin{array}{c}\text { Institutional } \\
\text { legacy }\end{array}$ & $\begin{array}{l}\text { Enterprise } \\
\text { leading }\end{array}$ & $\begin{array}{l}\text { Policy driving; } \\
\text { Regional } \\
\text { Revitalization as } \\
\text { national strategy }\end{array}$ & $\begin{array}{l}\text { Official-civil } \\
\text { governance }\end{array}$ & $\begin{array}{l}\text { The formation of } \\
\text { destination image }\end{array}$ \\
\hline Action & $\begin{array}{l}\text { Protection; } \\
\text { Investigation }\end{array}$ & $\begin{array}{l}\text { Self- } \\
\text { development; } \\
\text { Corporate } \\
\text { museums }\end{array}$ & $\begin{array}{l}\text { Transformation of } \\
\text { old industrial area; } \\
\text { Urban renewal; } \\
\text { Cultural policy for } \\
\text { Creative City }\end{array}$ & $\begin{array}{l}\text { Participation of } \\
\text { local residents; } \\
\text { Publicity and } \\
\text { promotion; Tourist } \\
\text { Increasing }\end{array}$ & $\begin{array}{l}\text { More industrial } \\
\text { enterprises start tourism } \\
\text { business; product } \\
\text { innovation }\end{array}$ \\
\hline \multirow[t]{2}{*}{ Phenomenon } & $\begin{array}{l}\text { Initial } \\
\text { conditions }\end{array}$ & $\begin{array}{l}\text { Restrictive } \\
\text { industrial } \\
\text { tourism activity }\end{array}$ & $\begin{array}{l}\text { Improvement } \\
\text { of industrial } \\
\text { tourism }\end{array}$ & $\begin{array}{l}\text { Diversified } \\
\text { tourist market }\end{array}$ & $\begin{array}{l}\text { Rich variety of high } \\
\text { quality tourism products; } \\
\text { Spillover into cultural } \\
\text { industry and Commerce }\end{array}$ \\
\hline & $\begin{array}{l}\text { Lock-in } \\
\text { phase }\end{array}$ & $\begin{array}{l}\text { Path dependence } \\
\text { phase }\end{array}$ & $\begin{array}{l}\text { Path creation } \\
\text { phase }\end{array}$ & $\begin{array}{l}\text { Path development } \\
\text { phase }\end{array}$ & $\begin{array}{l}\text { Adaptation of local } \\
\text { tourism path phase }\end{array}$ \\
\hline
\end{tabular}

Figure 4. A model of industrial heritage tourism evolution path. Source: own draft.

In the path development phase, specific actions were taken to promote industrial heritage tourism, including the design of tour routes, market promotion, efficient allocation of resources, infrastructure improvement, and community-based networking. In the adaptation of the local tourism path phase, as the number of tourists increased, more technology and manufacturing enterprises were motivated to participate in industrial heritage tourism. Meanwhile, local governments, enterprises, and community groups worked together, to develop new tourism products to adapt to the new markets.

\subsection{Path Dependence in Industrial Heritage Tourism Development}

As a theoretical concept, path dependence is based on the straightforward assumption that "history matters". Our findings show that there is a multiplicity of path dependence existing in the term of tourism products. Figure 5 summarizes the industrial resource- 
based path dependence and its new path development of industrial tourism products in Kitakyushu. At the very beginning, the development of tourism products in Kitakyushu largely depended on the industrial heritage: Higashida No. 1 Blast Furnace and Yawata Steelworks. Although new technologies and products (e.g., eight view sightseeing, outdoor education) were integrated to promote industrial tourism during the sequent stages, they were strongly based on the existing industrial heritages.

Similarly, strong institutional path dependence could be observed in the development of industrial tourism in Kitakyushu. The findings show that the past institutional structure has influenced the further restructuring and competition of industrial tourism development. Protection of industrial heritage was a thematic priority, yet this was often not wellconnected to tourism in the early years. With the implementation of regional policies of local governments, the willingness of private enterprises to carry out industrial heritage tourism increased. Meanwhile, high-technology enterprises have gradually penetrated the tourism sector, and developed a series of experiential industrial tourism projects over time.

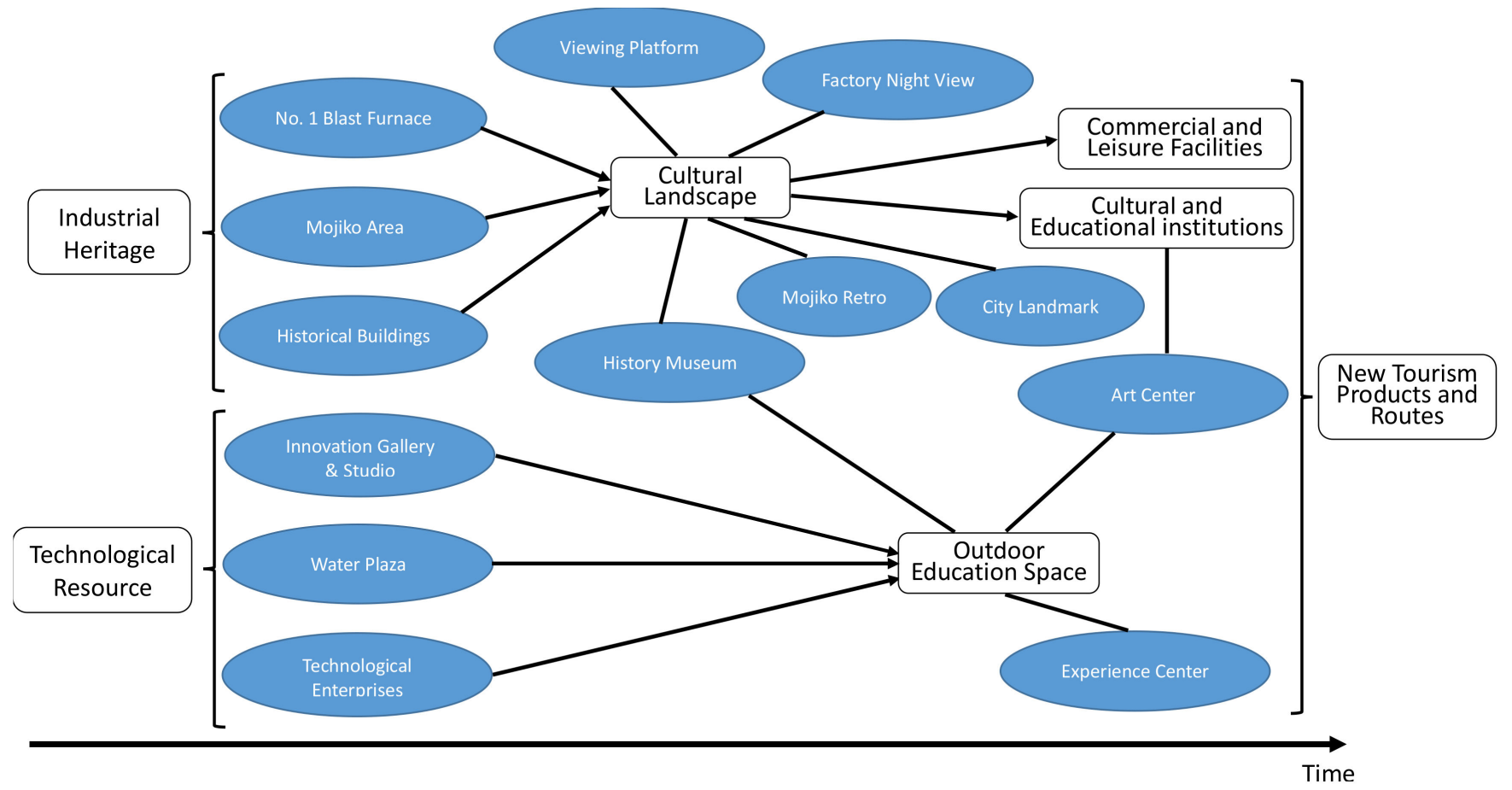

Figure 5. The resource-based path development of industrial heritage tourism products in Kitakyushu. Source: own draft.

\subsection{Path Creation by Regional Policies and Cooperation}

Regional policy is one of the most significant factors influencing how tourism develops and becomes a facilitator of sustainable development. In the case of Kitakyushu, the local government's urban renewal and cultural policy undoubtedly played a considerable role. In the 2000s, despite the many efforts that were taken by private enterprises to promote the development of tourism in Kitakyushu City, domestic and foreign visitor numbers remained relatively lower compared to other Kyushu regions. Our case study shows that the industrial heritages cannot be automatically transformed into economic resources for regional revitalization without intervention and participation from governments, enterprises, and other actors. Nevertheless, as Hall (2008) pointed out, the strategic efforts by local public actors are of significant importance to stimulate the development of industrial heritage tourism [68].

In the case of Kitakyushu City, the strategic stakeholders involved spanned across different organizations and institutions. Innovation and entrepreneurship are key concepts related to path creation, highlighting the potential of entrepreneurs to lead and operationalize visions of new pathways $[69,70]$. However, efforts to create new paths through 
"mindful deviation" from existing structures and development trajectories could meet resistance and inertia. Local governments played a crucial role in creating new paths, and they often supported traditional manufacturing enterprises in developing tourism-oriented projects. Local citizens were also invited to participate in promoting industrial heritage tourism, for example, participation in project planning.

\section{Conclusions}

It is wildly believed that industrial heritage sites have the potential to transform into modern tourist destinations. However, there is little knowledge about under what conditions and by whom they are transformed into tourist sites. Kitakyushu City has transformed from a declining industrial city of Japan, to a significant tourist attraction and World Heritage Site. Industrial heritage tourism has emerged as a new type of economic activity in Kitakyushu City, despite that it is still in its early development phase. The EEG provides an opportunity to better our understanding of the transformation into industrial heritage tourism and to demonstrate the usefulness of the path-dependent model in sustainable development of industrial tourism. However, industrial tourism can be developed in declining industrial cities, partly because of the new path created jointly by stakeholders. With the concepts of path dependence and path creation, we analyzed the transformation process of the industrial heritage of the Kitakyushu City in Japan.

Our research findings can be summarized as follows. First, in the early stages, participation of local enterprises, pilot development, and government supports play an important role. In particular, industrial heritage tourism has a high path dependence on the original industrial enterprises. Second, urban renewal under the guidance of local governments' cultural policies can be regarded as an essential condition for the development of industrial heritage tourism. The improvement of tourism infrastructure, the general survey, publicity, and the promotion of industrial heritage collectively provided strong foundations for the transformation of the Kitakyushu City into a major tourism destination in Japan. Third, the formation of the new path of industrial tourism largely comes from effective and frequent communication with local governments, enterprises, and community stakeholders.

Furthermore, similar to manufacturing sectors, booming industrial tourism is also inseparable from industrial and technological innovation. For declining industrial cities, the regional competitive advantage in tourism is also increasingly innovation-based [71]. From the perspective of EEG, innovations can emerge from a new combination of existing knowledge in the regional context. Industrial heritage tourism in Kitakyushu is based the combination of local industrial heritage and emerging and new technologies.

Author Contributions: Author Contributions: Conceptualization, Z.L. and Z.Z.; methodology, Z.Z. and Z.L.; writing—original draft preparation, Z.Z.; writing—review and editing, Z.L.; supervision, Z.L.; project administration, Z.Z. and Z.L.; funding acquisition, Z.Z. and Z.L. All authors have read and agreed to the published version of the manuscript.

Funding: This research is supported by the National Natural Science Foundation of China (No. 42001157), the Key Laboratory of Regional Sustainable Development Modeling Chinese Academy of Sciences (No. KF2020-09), the Strategic Priority Research Program (A) of Chinese Academy of Sciences (No. XDA19040403), and the Second Tibetan Plateau Scientific Expedition and Research Program (STEP) (No. 2019QZKK1007).

Institutional Review Board Statement: Not applicable.

Informed Consent Statement: Not applicable.

Data Availability Statement: The data supporting the reported results in the present study will be available on request from the corresponding author or the first author.

Conflicts of Interest: The author declares no conflict of interest. 


\section{References}

1. Halewood, C.; Hannam, K. Viking heritage tourism: Authenticity and commodification. Ann. Tour. Res. 2001, 28, 565-580. [CrossRef]

2. Hospers, G.J. Industrial heritage tourism and regional restructuring in the European Union. Eur. Plan. Stud. 2002, 10, 397-404. [CrossRef]

3. Jones, C.; Munday, M. Blaenavon and United Nations World Heritage Site status: Is conservation of industrial heritage a road to local economic development? Reg. Stud. 2001, 35, 585-590. [CrossRef]

4. Cudny, W.; Jolliffe, L.; Guz, A. Heritage event as tourist attraction: The case of Dymarki Swietokrzyskie, Poland. GeoJournal 2021. [CrossRef] [PubMed]

5. Somoza-Medina, X.; Monteserín-Abella, O. The Sustainability of Industrial Heritage Tourism Far from the Axes of Economic Development in Europe: Two Case Studies. Sustainability 2021, 13, 1077. [CrossRef]

6. Pardo, C.J. Valuation of Industrial Heritage in Terms of Sustainability: Some Cases of Tourist Reference in Spain. Sustainability 2020, 12, 9216. [CrossRef]

7. Hashimoto, A.; Telfer, D.J. Transformation of Gunkanjima (Battleship Island): From a coalmine island to a modern industrial heritage tourism site in Japan. J. Herit. Tour. 2017, 12, 107-124. [CrossRef]

8. Cossons, N. Why preserve the Industrial Heritage. In Industrial Heritage Re-Tooled: The TICCIH Guide to Industrial Heritage Conservation; Douet, J., Ed.; Carnegie Publishing Ltd.: Lancaster, UK; The International Committee for the Conservation of the Industrial Heritage (TICCIH): Lancaster, UK, 2012; pp. 6-16.

9. Jansen-Verbeke, M. Industrial Heritage: A Nexus for Sustainable Tourism Development. Tour. Geogr. 1999, 1, 70-85. [CrossRef]

10. Bottero, M.; D'Alpaos, C.; Oppio, A. Ranking of Adaptive Reuse Strategies for Abandoned Industrial Heritage in Vulnerable Contexts: A Multiple Criteria Decision Aiding Approach. Sustainability 2019, 11, 785. [CrossRef]

11. Sabaté, J. Paisajes culturales. El patrimonio como recurso básico para un nuevo modelo de Desarrollo (Heritage as a basic resource for a new development model). Urban 2004, 9, 8-29.

12. Pardo Abad, C.J. Turismo y Patrimonio Industrial. Un Análisis Desde la Perspectiva Territorial (Tourism and Industrial Heritage. An Analysis from the Territorial Perspective); Editorial Síntesis: Madrid, Spain, 2008.

13. Morishima, T. Process of conservation and utilization of the heritages of industrial-modernization in a former industrial town: The Omuta/Arao Areas. Geogr. Rev. Jpn. Ser. A 2011, 84, 305-323. (In Japanese)

14. Boschma, R.; Martin, R. Editorial: Constructing an evolutionary economic geography. J. Econ. Geogr. 2007, 7, 537-548. [CrossRef]

15. Brouder, P. Evolutionary economic geography: Reflections from a sustainable tourism perspective. Tour. Geogr. 2017, 19, 438-447. [CrossRef]

16. Mackinnon, D.; Dawley, S.; Steen, M.; Menzel, M.; Karlsen, A.; Sommer, P.; Normann, H.E. Path creation, global production networks and regional development: A comparative international analysis of the offshore wind sector. Prog. Plan. 2018, 130, 1-32. [CrossRef]

17. Randelli, F.; Romei, P.; Tortora, M. An evolutionary approach to the study of rural tourism: The case of Tuscany. Land Use Policy 2014, 38, 276-281. [CrossRef]

18. Paniccia, P.M.A.; Leoni, L. Co-evolution in tourism: The case of Albergo Diffuso. Curr. Issues Tour. 2019, 22, 1216-1243. [CrossRef]

19. Brouder, P.; Fullerton, C. Exploring Heterogeneous Tourism Development Paths: Cascade Effect or Co-evolution in Niagara? Scand. J. Hosp. Tour. 2015, 15, 152-166. [CrossRef]

20. Edwards, J.; Llurdes, J. Mines and quarries: Industrial heritage tourism. Ann. Tour. Res. 1996, 23, 341-363. [CrossRef]

21. Hudson, R. Rethinking change in old industrial regions: Reflecting on the experiences of North East England. Environ. Plan. A 2005, 37, 581-596. [CrossRef]

22. Martin, R.; Sunley, P. Path dependence and regional economic evolution. J. Econ. Geogr. 2006, 6, 395-437. [CrossRef]

23. Martin, R. Roepke Lecture in economic geography-rethinking regional path dependence: Beyond lock-in to evolution. Econ. Geogr. 2010, 86, 1-27. [CrossRef]

24. $\mathrm{Hu}, \mathrm{X}$. From coal mining to coal chemicals? Unpacking new path creation in an old industrial region of transitional China. Growth Chang. 2017, 48, 233-245. [CrossRef]

25. Boschma, R. Towards an evolutionary perspective on regional resilience. Reg. Stud. 2015, 49, 733-751. [CrossRef]

26. Hassink, R. Regional resilience: A promising concept to explain differences in regional economic adaptability? Camb. J. Reg. Econ. Soc. 2010, 3, 45-58. [CrossRef]

27. Frenken, K.; Van Oort, F.; Verburg, T. Related variety, unrelated variety and regional economic growth. Reg. Stud. 2007, 41, 685-697. [CrossRef]

28. Neffke, F.; Henning, M.; Boschma, R. How do regions diversify over time? Industry relatedness and the development of new growth paths in regions. Econ. Geogr. 2011, 87, 237-265. [CrossRef]

29. Boschma, R.; Frenken, K. Some notes on institutions in evolutionary economic geography. Econ. Geogr. 2009, 85, 151-158. [CrossRef]

30. Morgan, K.J. Path dependence and the state: The politics of novelty in old industrial regions. In Re-Framing Regional Development: Evolution, Innovation and Transition, Regions and Cities; Routledge: Abingdon, UK, 2012; p. 340.

31. Bailey, D.; Bellandi, M.; Caloffi, A.; De Propris, L. Place-renewing leadership: Trajectories of change for mature manufacturing regions in Europe. Policy Stud. 2010, 31, 457-474. [CrossRef] 
32. Dawley, S. Creating new paths? Offshore wind, policy activism, and peripheral region development. Econ. Geogr. 2014, 90, 91-112. [CrossRef]

33. $\mathrm{Hu}, \mathrm{X}$.; Yang, C. Building a role model for rust belt cities? Fuxin's economic revitalization in question. Cities 2018, 72, 245-251. [CrossRef]

34. Isaksen, A. Industrial development in thin regions: Trapped in path extension? J. Econ. Geogr. 2015, 15, 585-600. [CrossRef]

35. Hassink, R.; Isaksen, A.; Trippl, M. Towards a comprehensive understanding of new regional industrial path development. Reg. Stud. 2019, 53, 1636-1645. [CrossRef]

36. Isaksen, A.; Trippl, M. Exogenously-led and policy-supported new path development in peripheral regions: Analytical and synthetic routes. Econ. Geogr. 2016, 93, 436-457. [CrossRef]

37. Martin, H.; Martin, R.; Zukauskaite, E. The multiple roles of demand in new regional industrial path development: A conceptual analysis. Environ. Plan. A 2019, 51, 1741-1757. [CrossRef]

38. Hudson, K. World Industrial Archaeology; CUP Archive: London, UK, 1979.

39. Krige, S. 'The power of Power': Power stations as industrial heritage and their place in history and heritage education. Yesterday Today 2010, 5, 107-126.

40. Palmer, M. Industrial Archaeology: Principles and Practice; Routledge: Abington-on-Thames, UK, 2012.

41. Green, G.P.; Sanchez, L. Does manufacturing still matter? Popul. Res. Policy Rev. 2007, 26, 529-551. [CrossRef]

42. Coscia, C.; Lazzari, G.; Rubino, I. Values, memory, and the role of exploratory methods for policy-design processes and the sustainable redevelopment of waterfront contexts: The case of Officine Piaggio (Italy). Sustainability 2018, 10, 2989. [CrossRef]

43. Pardo, C.J. The post-industrial landscapes of Riotinto and Almadén, Spain: Scenic value, heritage and sustainable tourism. J. Herit. Tour. 2017, 12, 331-346. [CrossRef]

44. Nikolic, M.; Drobnjak, B.; Kuletin Culafic, I. The possibilities of preservation, regeneration and presentation of industrial heritage: The case of Old Mint “A.D." on Belgrade Riverfront. Sustainability 2020, 12, 5264. [CrossRef]

45. Yin, Y.M.; Liu, Z.G.; Dunford, M.; Liu, W.D. The 798 Art District: Multi-scalar drivers of land use succession and industrial restructuring in Beijing. Habitat Int. 2014, 46, 147-155. [CrossRef]

46. Szromek, A.R.; Herman, K.; Naramski, M. Sustainable development of industrial heritage tourism-A case study of the Industrial Monuments Route in Poland. Tour. Manag. 2021, 83, 104252. [CrossRef]

47. Evans, G. Hard branding the city-From Prado to Prada. Int. J. Urban Reg. Res. 2003, 27, 417-440. [CrossRef]

48. Copić, S.; ĐorđevićA, J.; Lukić, T.; Stojanović, V.; Đukičin, S.; Besermenji, S.; Tumarić, A. Transformation of industrial heritage: An example of tourism industry development in the Ruhr area (Germany). Geogr. Pannonica 2014, 18, 43-50. [CrossRef]

49. Anton, C.S.; Wilson, J. The evolution of coastal tourism destinations: A path plasticity perspective on tourism urbanization. J. Sustain. Tour. 2017, 25, 96-112.

50. Brouder, P. Evolutionary economic geography and tourism studies: Extant studies and future research directions. Tour. Geogr. 2014, 16, 540-545. [CrossRef]

51. Ashworth, G.; Page, S.J. Urban tourism research: Recent progress and current paradoxes. Tour. Manag. 2011, 32, 1-15. [CrossRef]

52. Duran, C. Governance for the Tourism Sector and Its Measurement; UNWTO Statistics and TSA Issue Paper Series STSA/IP/2013/01. Available online: https:/ / www.e-unwto.org/doi/epdf/10.18111/9789284415632 (accessed on 15 November 2020).

53. Mutana, S.; Mukwada, G. Are policies and guidelines shaping tourism sustainability in South Africa? Critical success factors for tourism sustainability governance in the Drakensberg region. Tour. Hosp. Res. 2020, 20, 198-209. [CrossRef]

54. Jamal, T.; Camargo, B.A. Tourism governance and policy: Whither justice? Tour. Manag. Perspect. 2018, 25, 205-208. [CrossRef]

55. Yachin, J.M.; Ioannides, D. "Making do" in rural tourism: The resourcing behaviour of tourism micro-firms. J. Sustain. Tour. 2020, 28, 1003-1021. [CrossRef]

56. Cobbing, A. Kyushu: Gateway to Japan; Global Oriental: Folkestone, UK, 2009.

57. Shapira, P. Industrial restructuring and economic development strategies in a Japanese steel town: The case of Kitakyushu. Town Plan. Rev. 1990, 61, 389-411. [CrossRef]

58. Ortiz-Moya, F. Green growth strategies in a shrinking city: Tackling urban revitalization through environmental justice in Kitakyushu City, Japan. J. Urban Aff. 2020, 42, 312-332. [CrossRef]

59. Ortiz-Moya, F.; Moreno, N. Filming industrial Japan: Kitakyushu, rise and decline of the iron town. Reg. Stud. Reg. Sci. 2015, 2, 480-488. [CrossRef]

60. Matsui, K. An example of preservation and utilization of modern heritage in Kitakyushu. Q. Archaeol. Stud. 2003, 50, 1-5. (In Japanese)

61. Cabinet Secretariat of Japan. The Legislation of "Act on Overcoming Population Decline and Vitalizing Local Economy in Japan". Available online: http://www.cas.go.jp/jp/houan/140929_1/gaiyou.pdf (accessed on 17 November 2020).

62. METI. 33 Heritage Constellations of Industrial Modernization. 2007. Available online: https://www.meti.go.jp/policy/mono_ info_service/mono/creative/kindaikasangyoisan/pdf/isangun.pdf (accessed on 17 November 2020).

63. METI. 33 Heritage Constellations of Industrial Modernization, Vol. 2. 2008. Available online: https://www.meti.go.jp/policy/ mono_info_service/mono/creative/kindaikasangyoisan/pdf/isangun_zoku.pdf (accessed on 17 November 2020).

64. Morishima, T. Comparing Policy Responses for the Conservation and Utilization of the Heritage of Industrial Modernization. Eur. J. Environ. Earth Sci. 2014, 9, 102-117. (In Japanese) 
65. Sun, B.; Ikebe, K. A Categorization Research of Heritage Constellations of Industrial Modernization. Mod. Environ. Sci. Eng. 2018, 4, 856-866.

66. Deng, A.; Lu, J.; Zhao, Z. Rural destination revitalization in China: Applying evolutionary economic geography in tourism governance. Asia Pac. J. Tour. Res. 2021, 26, 215-230. [CrossRef]

67. Ma, M.; Hassink, R. An evolutionary perspective on tourism area development. Ann. Tour. Res. 2013, 41, 89-109. [CrossRef]

68. Hall, C.M. Tourism Planning. Policies, Processes and Relationships, 2nd ed.; Pearson Prentice Hall: Harlow, UK, 2008.

69. Brouder, P.; Eriksson, R.H. Tourism evolution: On the synergies of tourism studies and evolutionary economic geography. Ann. Tour. Res. 2013, 43, 370-389. [CrossRef]

70. Gill, A.M.; Williams, P.W. Mindful deviation in creating a governance path towards sustainability in resort destinations. Tour. Geogr. 2014, 16, 546-562. [CrossRef]

71. Meekes, J.F.; Buda, D.M.; Roo, G. Adaptation, interaction and urgency: A complex evolutionary economic geography approach to leisure. Tour. Geogr. 2017, 19, 525-547. [CrossRef] 